\title{
Evaluation of P53 and Some Blood Parameters In Women Diagnosed With Breast Cancer
}

Ghazwan Sabah Kamel $(\mathrm{BSc})^{1}$, Salih Mahdi Salman $(\mathrm{PhD})^{2}$ and Walaa Najim $\operatorname{Abood}(\mathrm{PhD})^{3}$

\section{Abstract}

Background:Tumor suppressor genes (including P53) are cancer suppressor genes. Mutations in these genes contribute to the development of cancer ( including breast cancer) since its role in controlling cell growth.

Objective: To Evaluate the status of P53 and determination some blood parameters.

Patients and Methods: Fifty female patients having primary breast carcinoma or breast mass and their age range from (17- 78 years), were included in this case control study. Other 50 relative to the patient women non breast carcinoma as controls, their age range from (2165 years). ELISA test was used to evaluate the status of P53 in serum of breast cancer women and relative control non breast cancer women. Blood samples are collected from both patients women and relative female, $5 \mathrm{ml}$ syringe used to collect blood. $3 \mathrm{ml}$ of collected venous blood placed in blood tubes with specific gel to facilitate separation of serum and centrifuged at 1400 r.p.m for 10 minutes then serum is collected in collecting tube and store at -20 until use. $2 \mathrm{ml}$ of collecting blood placed in EDTA tube for CBC (complete blood account) by Medonic M32 3. Diff Hematology Analyzer, in which WBCs and platelet count included.

Results: The titer (Mean \pm SD) of p53 in breast cancer women was $(140.7 \mathrm{pg} / \mathrm{mL} \pm 60.9$ $\mathrm{pg} / \mathrm{mL}$ ) which is less than those of control non breast cancer women which their titer was (192.6 $\mathrm{pg} / \mathrm{mL} \pm 285.5 \mathrm{pg} / \mathrm{mL})$ with non-significant difference $(\mathrm{P}<0.05)$ between two groups. The level (Mean \pm SD) of total WBC number in breast cancer group was $(8.5 \mathrm{pg} / \mathrm{mL} \pm 2.5 \mathrm{pg} / \mathrm{mL})$ $\mathrm{x} 103$ cells/mm3 which was higher significant $(\mathrm{P}<0.05)$ than those of control non breast cancer women $(7.5 \mathrm{pg} / \mathrm{mL} \pm 1.4 \mathrm{pg} / \mathrm{mL}) \times 103$ cells $/ \mathrm{mm} 3$. The level of (Mean \pm SD) platelet number of breast cancer women was $(344.8 \mathrm{pg} / \mathrm{mL} \pm 116.8 \mathrm{pg} / \mathrm{mL}) \times 103$ cells $/ \mathrm{mm} 3$ which was higher nonsignificant $(\mathrm{P}<0.05)$ than those of control non breast cancer women $(316.7 \mathrm{pg} / \mathrm{mL} \pm 95.8 \mathrm{pg} / \mathrm{mL})$ $\mathrm{x} 103$ cells $/ \mathrm{mm} 3$. There is no correlation between total WBC and platelet number in non breast cancer women but there is non significant correlation in breast cancer women . Lymphocyte and neutrophile number and percentage was significantly higher in breast cancer women than control non breast cancer women.

Conclusion: The activity of P53 is decreased which may contributed to cancer while blood parameter were elevated in the serum of breast cancer women.

Keywords: Breast cancer, p53, Tumor suppressor genes, Blood parameters

Corresponding Author: ghazwanalmobasher@gmail.com 
Received: $21^{\text {th }}$ October 2018

Accepted: $23^{\text {th }}$ December 2018

\section{${ }^{1}$ College of Science- University of Diyala-Diyala - Iraq \\ ${ }^{2,3}$ College of Medicine - University of Diyala-Diyala - Iraq}

\section{Introduction}

Tumor suppressor genes refer to those genes whose function lost result in malignancy promotion[1]. P53 is tumor suppressor genes that prevent cancer initiation and growth since its important role in cell cycle regulation, apoptosis induction and DNA repair [2]. Breast cancer is the most common cancer and the leading cause of death in women[3]. Among all new cancer cases in Iraqi females, breast cancer alone counted $31 \%$ [4]. Many risk factors of breast cancer are known such as age, family history, menstrual history, genetic factors, menopause, and radiations, are not easily modifiable while other risk factors such as use of hormone replacement therapy, alcohol consumption, smoking and breast feeding are modifiable[5]. Lymphocytes, including $\mathrm{T}$ cells, $\mathrm{T}$ regulatory ( $\mathrm{T}$ reg) cells, and natural killer (NK) cells, and cytokines that they released are associated in both primary and secondary prevention of breast cancer . Cancer prognosis maybe related to status of immune system function [6] .

\section{Patients and Methods}

This study is case control study . Samples are collected from medical city Baghdad teaching hospital and Baquba teaching hospital during the period from October $1 / 10 / 2017$ to May 1/4/2018. Samples obtained from women with breast cancers and women with breast mass that diagnosed according to doctor records and improvement of laboratory examination. Non-breast cancer female whom relative to breast cancer women are share as control group in this study. Samples is collected from patient women after excision the breast mass or cancer. Blood samples are collected from both patients women and relative female, $5 \mathrm{ml}$ syringe used to collect blood. $3 \mathrm{ml}$ of collected venous blood placed in blood tubes with specific gel to facilitate separation of serum and centrifuged at 1400 r.p.m for 10 minutes then serum is collected in collecting tube and store at -20 until use. $2 \mathrm{ml}$ of collecting blood placed in EDTA tube for CBC (complete blood account) by Medonic M32 3. Diff Hematology Analyzer, in which WBCs and platelet count included.

Human cellular tumor antigen p53 ELISA kit is provided by sunlong biotech co.,ltd (china)(SL1323Hu) was used for detection of P53 in the serum of both breast cancer women and non breast cancer women.

\section{Statistical analysis}

The statistical analysis had been done by using SPSS version 20 statistical analysis software to analyze the data. The data are presented as mean $\pm \mathrm{SD}$, The statistical examination of data was done through T-test and correlation. Significance was determined by using a $\mathrm{P}$ value $<0.05$. 


\section{Results}

The total WBC number in breast cancer number of breast cancer women was higher group was higher significant $(\mathrm{P}<0.05)$ than control as shown in figure (1). The platelet non-significant than control group as shown in Figure(2).

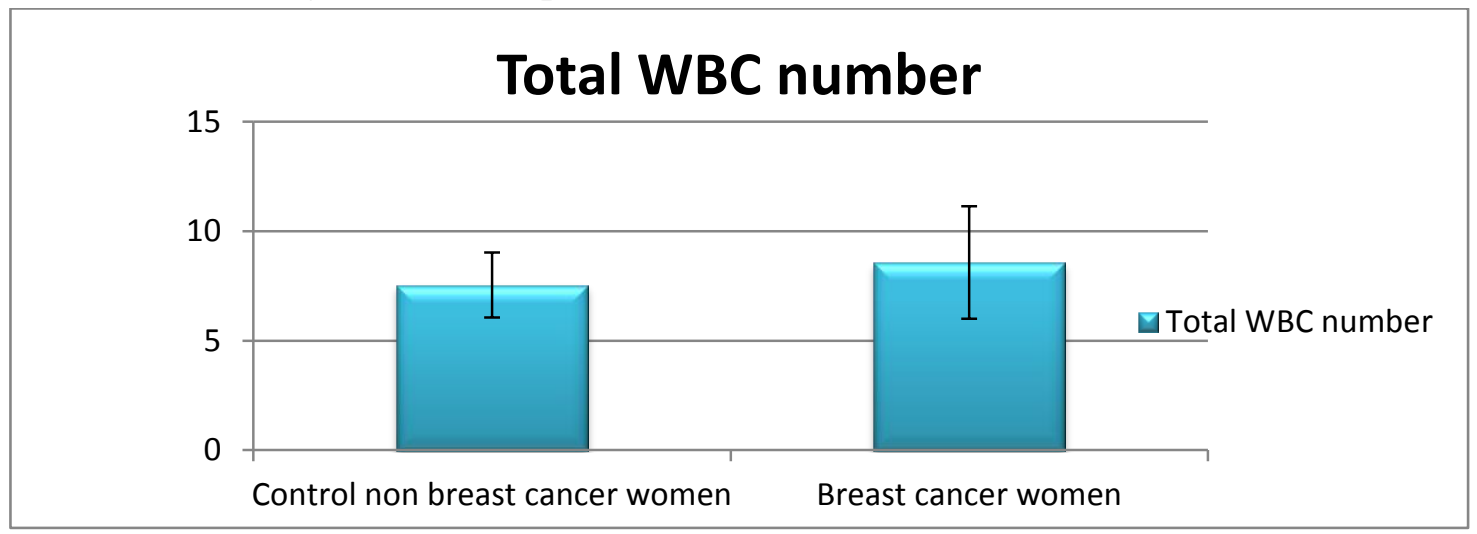

Figure (1)B Presented the level of total WBC in the breast cancer and non breast cancer women. The data was presented as (Mean $\pm \mathrm{SD})$, Significantly at $\mathrm{P}$ value $<0.05$.

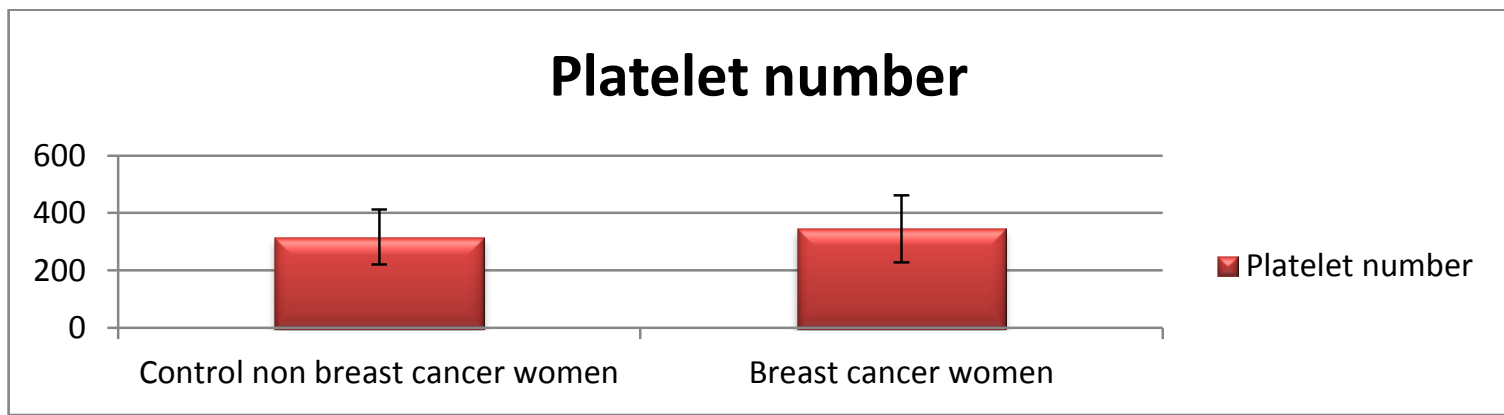

Figure (2): Presented the level of platelet in breast cancer and non breast cancer women . The data was presented as (Mean $\pm \mathrm{SD}$ ), Significantly at $\mathrm{P}$ value $<0.05$.

As shown in Table (1) there is no positive correlation in breast cancer women correlation between total WBC, platelet as presented in Table (2) number in non breast cancer women but 
Table(1 ):The correlation between total WBC and platelet number among control non breast cancer women.

\begin{tabular}{|c|c|c|c|}
\hline & & Total WBC numb & Platelet number \\
\hline \multirow[t]{3}{*}{ Total WBC number } & Pearson Correlation & 1 & .006 \\
\hline & Sig. (2-tailed) & & .973 \\
\hline & $\mathrm{N}$ & 37 & 37 \\
\hline \multirow[t]{3}{*}{ Platelet number } & Pearson Correlation & .006 & 1 \\
\hline & Sig. (2-tailed) & .973 & \\
\hline & $\mathrm{N}$ & 37 & 37 \\
\hline
\end{tabular}

Table (2): The correlation between total WBCs and platelet number in breast cancer women.

\begin{tabular}{|c|c|c|c|}
\hline & & $\begin{array}{c}\text { Total WBC } \\
\text { number }\end{array}$ & $\begin{array}{l}\text { Platelet } \\
\text { number }\end{array}$ \\
\hline \multirow[t]{3}{*}{ Total WBC number } & Pearson Correlation & 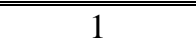 & .144 \\
\hline & Sig. (2-tailed) & & .339 \\
\hline & $\overline{\mathrm{N}}$ & 46 & 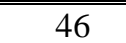 \\
\hline \multirow[t]{3}{*}{ Platelet number } & Pearson Correlation & .144 & 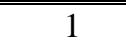 \\
\hline & Sig. (2-tailed) & .339 & \\
\hline & $\mathrm{N}$ & 46 & 46 \\
\hline
\end{tabular}

Neutrophil and lymphocyte numbers and significant $(\mathrm{P}<0.05)$ than control as shown in percentage in breast cancer group was higher Table (4-3).

Table (3): The number of neutrophil and lymphocyte among breast cancer and non breast cancer women.

\begin{tabular}{|c||c|c|c|c|c||}
\hline & Groups & N & Mean & $\begin{array}{c}\text { Std. } \\
\text { Deviati } \\
\text { on }\end{array}$ & $\begin{array}{c}\text { Std. } \\
\text { Error } \\
\text { Mean }\end{array}$ \\
\hline \hline \multirow{2}{*}{$\begin{array}{c}\text { Neutrophil } \\
\text { number }\end{array}$} & $\begin{array}{c}\text { Control non breast cancer } \\
\text { women }\end{array}$ & 37 & 4416.4 & 940.3 & 154.59 \\
\cline { 2 - 6 } & Breast cancer women & 46 & 5781.9 & 1715.3 & 252.916 \\
\hline \hline $\begin{array}{c}\text { Lymphocyte } \\
\text { number } \\
\text { Neutrophil \% }\end{array}$ & $\begin{array}{c}\text { Control non breast cancer } \\
\text { women }\end{array}$ & 37 & 2033.9 & 528 & 86.817 \\
\cline { 2 - 6 } & $\begin{array}{c}\text { Control non breast cancer } \\
\text { women }\end{array}$ & 37 & 58.7 & 7.7 & 1.267 \\
\cline { 2 - 6 } & Breast cancer women & 46 & 63.2 & 9.9 & 1.465 \\
\hline \hline lymphocyte \% & $\begin{array}{c}\text { Control non breast cancer } \\
\text { women }\end{array}$ & 37 & 26.8 & 7.2 & 1.194 \\
\cline { 2 - 6 } & Breast cancer women & 46 & 30.4 & 8.1 & 1.208 \\
\hline \hline
\end{tabular}


Table (4): Titer of p53 according to studied group.

\begin{tabular}{|c||c||c|c||}
\hline Group & $\mathrm{N}$ & P53 titer pg/mL & $\begin{array}{c}\text { BRCA1 titer } \\
\mathrm{pg} / \mathrm{mL}\end{array}$ \\
\hline \hline Control non breast cancer women & 37 & $192.6 \pm 285.5$ & $14.9 \pm 9.7$ \\
\hline \hline Breast cancer women & 46 & $140.7 \pm 60.9$ & $13.1 \pm 5.2$ \\
\hline
\end{tabular}

\section{Discussion}

This study showed significantly increased in total WBCs and platelet account in breast cancer patient than control subject and this agree with Akinbami et al (2013)[7] study who reported that mean of WBCs counts and platelet counts were higher in cases than control and he demonstrated this result due to the fact that neoplasms were associated with neutrophilia. Higher total WBCs can be due to breast cancer or disease or patient have breast mass instead of breast cancer because our collection of tissue sample was performed from breast mass as well as breast cancer and those patients not treated with chemotherapy according to the data collected from the patients. Elevated platelet account can be due to reactive thrombocytosis as a result of cancer induce anemia. In this study the result was shown positive correlation between WBCs count and breast cancer patient . In the previous study Margolis et al (2007)[8] demonstrated that there is strong association between WBCS count and invasive breast cancer mortality .Heavily infiltration of inflammatory cells occur in most tumors which in turn produce cytokines and chemokines that regulate the growth, migration, and differentiation of tumor and stromal cells [9]. Positive correlation of platelet with breast cancer patient in this study is agree with the study of Jarintanan et al (2015)[10] who revealed that platelet have good correlation with breast cancer patient. The activation of platelet by contact with breast tumor cells leading to the release of hundreds of growth factors, cytokines, chemokines and angiogenesis mediators that could influence tumor growth and metastasis [11]. In current study the number and percentage of neutrophil and lymphocyte were higher in breast cancer women than control which agree with Akinbami et al (2013)[12] study who revealed that the percentage of neutrophil and lymphocyte were higher in breast cancer women compared to control. Increase neutrophil account may be due to neutrophilia which associated with neoplasms. Tumor host with neutrophilia associated with poor prognosis because it can inhibit the activity of cytotoxic $\mathrm{T}$ cell and natural killer cells [13]. In the adaptive immune system, lymphocytes 
exhibit antitumor activity. Tumor recurrence and survival predicted by Peripheral lymphocyte count [14]. Patients have better survival with elevated tumor-infiltrating lymphocyte counts [15]. In this study the result of mean p53 was higher with no significant difference between two groups (higher in control than patients) and this disagree with study done by al-hassan (2011)[16] that show there is significant increase in mean serum level of p53-Ab in patients compared to control . 28 gene (including 17 previously reported) were identified as p53 repression gene, these genes are involved in the regulation of various cellular functions and module that respond to genotoxic stress simultaneously in breast cancer cells (these genes suppress in breast cancer) and these genes might function as a core module of p53-repressed genes under various conditions and/or cell lines. The expression of p53 in breast cancer ranged from $9 \%$ to $69 \%$ [17], high expression of p53 may be due to genetic or environmental factors that dictate the p53 mutation type.

\section{Conclusions}

The activity of P53 in serum of breast cancer women are decreased since their level was low in the serum of breast cancer women . Blood parameter (Total WBCs, Platelets, Lymphocytes and Neutrophils were elevated in breast cancer women.

\section{References}

[1]Osborne, Cynthia, Paschal Wilson, and Debu Tripathy. "Oncogenes and tumor suppressor genes in breast cancer: potential diagnostic and therapeutic applications." The oncologist 9.4 (2004): 361-377.

[2]Lacroix, Marc, Robert-Alain Toillon, and Guy Leclercq. "p53 and breast cancer, an update." Endocrine-related cancer 13.2 (2006): 293-325.

[3]Black, Margot H., et al. "Serum total and free prostate-specific antigen for breast cancer diagnosis in women." Clinical cancer research 6.2 (2000): 467-473.

[4]Al Hasnawi, Salih Mehdi, et al. "Cancer in Iraq: Distribution by primary tumor site." New Iraqi J Med 5.1 (2009): 5-8.

[5]Chlebowski, Rowan T., et al. "Ethnicity and breast cancer: factors influencing differences in incidence and outcome." Journal of the National Cancer Institute 97.6 (2005): 439-448.

[6]Standish, Leanna J., et al. "Breast cancer and the immune system." Journal of the Society for Integrative Oncology 6.4 (2008): 158.

[7]Akinbami, Akinsegun, et al. "Full blood count pattern of pre-chemotherapy breast cancer patients in Lagos, Nigeria." Caspian journal of internal medicine 4.1 (2013): 574.

[8]Margolis, Karen L., et al. "Prospective study of leukocyte count as a predictor of incident breast, colorectal, endometrial, and lung cancer and mortality in postmenopausal women." Archives of internal medicine 167.17 (2007): 1837-1844. [9]Rollins, Barrett J. "Inflammatory chemokines in cancer growth and progression." European Journal of Cancer42.6 (2006): 760-767.

[10]Jarintanan, Faongchat, et al. "Comparison of automated blood cell 
counting of breast cancer patients by Advia 120 and Sysmex XT 4000i." Science \& Technology Asia 20.1: 12-17.

[11]Johnson, Kelly Elizabeth, et al. "Platelets

Promote Breast Cancer Metastasis By

Reprogramming Tumor Cells to Produce IL-

8." (2015): 2233-2233.

[12]Yersal, Özlem, et al.

"Neutrophil/Lymphocyte and

Platelet/Lymphocyte Ratios are Not

Different among Breast Cancer Subtypes."

Asian Pacific journal of cancer prevention:

APJCP 18.8 (2017): 2227.

[13]De Giorgi, Ugo, et al. "Relationship between lymphocytopenia and circulating tumor cells as prognostic factors for overall survival in metastatic breast cancer." Clinical breast cancer 12.4 (2012): 264-269.

[14]Loi, S., et al. "Tumor infiltrating lymphocytes are prognostic in triple negative breast cancer and predictive for trastuzumab benefit in early breast cancer: results from the FinHER trial." Annals of oncology 25.8 (2014): 1544-1550.

[15]Al-Hassan, Ahmed AA. "Detection of serum anti-p53 antibodies in breast cancer patients." Al-Mustansiriyah Journal of Science 22.1 (2011): 7-12.

[16]Miyamoto, Takafumi, et al. "Identification of a p53-repressed gene module in breast cancer cells." Oncotarget 8.34 (2017): 55821.

[17]Børresen-Dale, Anne-Lise. "TP53 and breast cancer." Human mutation 21.3 (2003): 292-300. 